\title{
Mémek: mítoszok, félreértések és félelmek
}

A mémek fogalmát Richard Dawkins használta először, Az önző gén címủ könyvében, 1976-ban. A kezdetben sok ellenérzéssel fogadott “mém” Dennett energikus propagandakampányának köszönhetően támogatókra talált, s számos- jóllehet gyakran változó minőségư - könyv és cikk íródott róla. Dennett szerint a kulturális entitások a kiválasztódás-rendszer alapján fejlődnek, ha a Cui bono (Ki jár jól)? kérdésre a "kulturális tárgy" a válasz. Csak ebből a szemszögből érthetjük meg, hogy nemcsak a kultúra ôrzői és közvetítői, hanem kulturális entitások is vagyunk.

\section{Szerzői információ:}

Daniel C. Dennett

A Darwin veszélyes elmélete (Darwin's Dangerous Idea. Simon \& Schuster, 1995) címú könyv szerzôje, és jelenleg a Tufti Egyetemen a Kognitív Tudományok Központjának igazgatója. 1963ban diplomázott filozófiából a Harvard egyetemen, majd 1965-ben Oxfordban doktorált. Eddig megjelent könyvei: Content and Consciousness (1969), Brainstorms (1978), Elbow Room (1984), The Intentional Stance (1987), Consciousness Explained (1991), Darwin's Dangerous Idea (1995), és Kinds of Minds (1996). Több mint száz, az emberi elmével foglalkozó tudományos cikke jelent meg elsôsorban a Mesterséges intelligencia, a Viselkedés, az agy és a költészet ma, valamint az Esztétika és kritika címú folyóiratok hasábjain. 1987 óta az Amerikai

Tudományos Akadémia tagja.

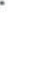


Danie 1 C. Dennet $t$

\section{Mémek: mítoszok, félreértések és félelmek}

A mémek fogalmát - Az önzố gén Címû́ kkönyvében Richard Dawkins használta először 1976-ban. A mű fogadtatása évekig igencsak hűvös maradt. Mostanában azonban, főleg annak az energikus propagandakampánynak köszönhetôen, amelyet a mém mémje mellett folytattam, elsôsorban a Tudat magyarázata és Darwin veszélyes ideája címú könyvekben, a mémek barátai lassan elkezdtek előjönni az árnyékból és újra áttekintésre került a mémekrôl íródott számos - jóllehet gyakran változó minôségû könyv és cikk. Jelenleg az Interneten virágzik azoknak a weboldalaknak a száma, amelyek az új tudomány, a memetika megszületését hirdetik. Ezeknek az oldalaknak a nagy része természetesen borzalmas, de ez egyáltalán nem meglepő. Hiszen Sturgeon törvénye szerint is minden dolognak a 95\%-a silány, értéktelen. A nehézség abban rejlik, - különösen a proto-memetika kialakulásának e korai szakaszában - hogy azt az 5\%-ot, ami valóban jó, azonosítani tudjuk. Sturgeon törvénye természetesen egyúttal azt is sejteti, hogy a mémeket és a memetikát érintố kritikák 95\%-a szintén silány, vacak. Ebból következốen tehát nem érdemes arra pazarolni az idônket, hogy minden egyes ostoba, aggodalom vezérelte ellenvéleményt megcáfoljunk. Beszédemben kísérletet teszek arra, hogy sokkal inkább a figyelemreméltó kérdésekre koncentráljak.

\section{Nézőpontok a kulturális evolúcióról}

Ha valaki azt állítja, hogy a kultúra evolvál, az már-már közhelynek számít - vagy legalábbis egy újabb ellentmondásos, spekulatív, és bizonyítékokat nélkülözô elmélet kinyilvánításának. Képzeljük el, hogy egy kulturális leltárt készítünk $t$ idôben: a leltár magába foglalja az összes nyelvet, szokásokat, ceremóniákat, épületeket, módszereket, eszközöket, mítoszokat, zenét, mûvészetet, és így tovább, beleértve mindent, ami a kultúrát alkotja. Az idő során ez a leltár változik. Néhány dolog kikerül a leltárból, néhány megsokszorozódik, mások egybeolvadnak, és megint mások kicserélődnek. (Amikor azt a terminust használom: „kicserélődik”, úgy értem, hogy az adott pillanatban közömbös, hogy ez a csere egy hasonló dologgal való helyettesítést jelenti, vagy a szóban forgó dolog átalakulását, megváltozását.) Ezeknek a változásoknak a szó szerinti dokumentálása azonban nem hoz létre tudományt, csupán egy adatbázist. Éppen ettôl lesz közhely az, hogy az idô elốrehaladtával a kultúra fejlôdik. A megválaszolandó kérdés tehát az, hogy hogyan értelmezhetőek az ebben az adatbázisban található minták. Van-e valamilyen jó elmélet vagy modell a kulturális evolúció magyarázatára? A legtöbb történész és antropológus leírásában megjelenő hagyományos mo- 
dell a kultúrát az emberek által birtokolt javak összességének tekinti, amellyel a gazdáik különbözô módokon - okosan, vagy kevésbé bölcsen -, sáfárkodnak. Az emberek gondosan megốrzik hagyományaikat a tûzgyújtás, házépítés, beszéd, számolás, igazságtétel, stb. területein. Úgy kereskednek a kulturális javakkal, mint az egyéb más árucikkekkel. Természetesen némely kulturális cikk, mint például a szekér, a tészta, vagy a csokoládétorta receptje, valóban kézzelfogható tárgyak, és így leírhatók a közgazdaság fogalmaival. Ebben a modellben az emberek önálló vagy független értelemmel rendelkeznek. Ha megfosztjuk az embert javaitól, akkor ott áll meztelenül, de értelemmel és jól informált vágyakkal telve. Amint felöltözik, felfegyverkezik, és megszerzi a számára szükséges javakat - növeli erejét és hatalmát, bonyolultabbá teszi a vágyait, és így tovább. Az ilyen jellegư gondolkodásban a különböző kulturális javak relatív, „reproduktív” erejét az emberek a piac keretein belül, a költség-haszon elemzés módszerével mérik. Ha a Coca-Cola jól fogy a világ minden táján, annak az az oka, hogy mind több és több ember akar Coca-Colát vásárolni. A reklámozás megbolondíthatja ốket. De azután a hirdetốkhöz fordulunk, illetve azokhoz, akik megbízzák ôket, hogy megtaláljuk a számításainkhoz szükséges megfelelő pontokat, amelyekhez a gazdasági értékfolyamatok rendelhetôk. Cui bono? Ki jár jól? Természetesen az áru szállítói, illetve azok, akik alkalmazzák ôket, hogy segítségükre legyenek.

Gyakran a biológusok is úgy értelmezik a jelenségek evolúcióját, hogy javakként kezelik őket. Ezek többek között egy egyed tápláléka, fészke, odúja, területe, szexuális partnere(i), illetve az egyed ideje és energiája. A költség-haszon elemzések rávilágítanak arra a gazdálkodásra, ami a közös környezetben élô különbözô fajok között zajlik. Jóllehet, nem minden „tulajdon” tekinthetố árucikknek. Az egyedet körülvevô legyeknek és bolháknak, vagy a testen felgyülemlő pornak és mocsoknak például nincs értéke, vagy egyenesen negatív értéke van. A biológusok normális esetben nem tekintik javaknak az adott fajjal szimbiózisban élóket, kivéve, ha a belólük származó előnyök kézzelfoghatóak.

Ez a nézőpont nem egyöntetûen megvilágosító erejú, még kevésbé kötelezô. Véleményem szerint azonban mind a biológusok, mind a közgazdászok (csakúgy, mint más társadalomtudósok) számára hasznos lehet, ha egy másik nézőpontot választanak arra, hogy megvizsgálják ezeket a jelenségeket. Egy olyan nézốpontot, amely teljesen jogosan, büszkén helyet biztosít a Cui bono? Ki jár jól? kérdésnek, mely aztán olyan alternatív válaszok felmerülését segíti elő, amelyek fölött gyakran átsiklunk. Ez Dawkins nézôpontja a mém szemszögéből, amely nemcsak felismeri, hanem nagyon komolyan is veszi annak a lehetôségét, hogy a kulturális entitások a szerint a kiválasztódás - rendszer szerint fejlődnek, amely csak akkor értelmezhetô, ha a Cui bono? Ki jár jól? kérdésre adott válasz az, hogy maga az a kulturális tárgy jár jól, melyen az adaptáció végbemegy.

Dawkins mémekrôl alkotott teóriája, ahogy azt egyetlen rövid fejezetben felvázolta Az önző gén címú múvében (Dawkins, 1976; 1993), aligha tekinthetố tudományos elméletnek, különösen akkor nem, ha más evolúciós modellekkel hasonlítjuk össze, melyeket olyan biológusok fejlesztettek ki, mint Cavalli-Sforza és Feldman (1981), Lumsden és Wilson (1981), valamint Boyd és Richerson (1985). E szerzôktől eltérốen Dawkins nem kínál formalizált fejlődést, matematikai modelleket, mennyiségi becsléseket, vagy a témába vágó empirikus kutatások eredményeinek szisztema- 
tikus vizsgálatát. Ehelyett Dawkins egy olyan ötlettel áll elő, amelyre a többi szerzók egyike sem fordít figyelmet. Véleményem szerint ez egy igen fontos gondolat, mivel ez lehet a kulcs annak megértéséhez, hogy miként lehetséges, hogy nem csak a kultúra őrzői és közvetítői lehetünk, hanem mi magunk is kulturális entitások vagyunk. Minden esetben, amikor a költség-haszon kérdése felmerül, fel kell tennünk a Cui bono? kérdését. A haszon önmagában nem magyarázó. Ső́t a nyereség, ha vákuumban van, akkor inkább egyfajta rejtéllyé válik. Addig, amíg nem vagyunk képesek kimutatni, hogy a nyereség valójában hogyan járul hozzá sokszorosítójának reproduktív erejéhez, addig csak ott van - talán csábítóan, de teljességgel képtelenül arra, hogy bármit is megmagyarázzon. Vegyünk például egy hangyát, amelyik fáradságosan kapaszkodik felfelé egy fúszálon. Miért teszi? Miért alkalmazkodik? Milyen előnye származik a hangyának abból, hogy ezt teszi? Ez nem a megfelelố kérdés, amit fel kell tennünk. A hangyának ebből semmi jó sem származik. A magyarázat arra, hogy mégis felfelé mászik a füszálon, az, hogy az agyát megtámadta egy horgasféreg (Dicrocoelium dendriticum), olyan apró paraziták egy csoportja, amelynek egy birka beleibe kell eljutnia ahhoz, hogy reprodukálódni tudjon. (Ridley, 1995:258) (A pisztráng felfelé, árral szemben úszik a folyón, ezek a kis paraziták pedig arra késztetik a hangyát, hogy felfelé másszon a fúszálon és így javítsák esélyeiket arra, hogy bejuthassanak egy éppen arra járó birka bélrendszerébe.) A haszon tehát nem a hangya, hanem a horgasféreg reprodukciós esélyeinek növelése. Dawkins rámutat, hogy a kulturális tárgyakat, mémeket is felfoghatjuk úgy, mint parazitákat. Tulajdonképpen, inkább egy egyszerú vírushoz hasonlíthatók, semmint egy féreghez. A mémek elviekben a génekhez hasonlatosak, a kulturális médiák reproduktív eszközei. Ugyanakkor közvetítő eszközzel, vagyis fenotípussal is rendelkeznek. Olyanok, mint a nem teljesen csupasz gének vagy mint a vírusok. (Dawkins, 1993) A vírusokhoz hasonlóan a mémeknél is van fenotípus/genotípus megkülönböztetés, bár meglehet, hogy ez éppen csak minimális. Alapjában véve a vírus egy attitűddel rendelkezô DNS (vagy RNS) lánc. Ehhez hasonlóan a mém egy attitűddel rendelkezô információcsomag (maga az információ és nem a közvetítô), valamiféle fenotípus- köntösbe öltöztetve, amelynek megkülönböztetô hatásai vannak a világra, ami ebből kifolyólag befolyásolja a reprodukcióra való esélyeit. A mémek területén a végsố haszonélvezô, amelyre a költség-haszon elemzések vonatkoznak, maga a mém, nem pedig az azt hordozó elem. Ezt természetesen nem úgy kell értenünk, mint egy merész empirikus kijelentést, amely kizárja (például) az egyes humán ágensek örökítésben, megbecsülésben, és a kulturális tárgyak terjedésének és fennmaradásának biztosításában játszott szerepét. Ez a véleményünk inkább javaslat egy olyan nézőpont elfogadására, amelyból a különbözố empirikus kijelentések széles körét vizsgálhatjuk meg és az azokat alátámasztó bizonyítékokat egy olyan semleges környezetben szemlélhetjük, amely elốítéletek nélkül kezeli ezeket az égetô kérdéseket.

A horgasféreggel való összehasonlításban arra késztettük az olvasót, hogy úgy gondoljon a mémre, mint egy parazitára, amelyik a saját reprodukciós érdekeit követve irányítja a szervezetet, amelyben él. Ugyanakkor észben kell tartanunk, hogy a szimbiózisban élőket három alapvető kategóriába sorolhatjuk:

paraziták, amelyek jelenléte rontja a gazdaszervezet fizikai állapotát; 
kommenæalisták, amelyek jelenléte közömbös;

mutualisták, amelyeknek jelenléte kifejezetten javítja mind a saját, mind a gazdaszervezet fizikai állapotát.

Mivel ezek a változatok egy folyamatos skálán helyezkednek el, nem szükséges teljesen precíz határokat húznunk, ahogy azt sem tudjuk közvetlenül, gyakorlati tesztekkel mérni, hogy mikor csökken egy bizonyos haszon szintje nullára, vagy fordul át károkozásba. Ugyanakkor azért a modellek lehetôvé teszik, hogy körüljárjuk az ilyen fordulatok következményeit. A legfontosabb pont, amire rá kell mutatnunk itt az, hogy a mémek esetében is számítanunk kell a fenti három típus jelenlétére. Ez azt jelenti például, hogy hiba lenne azt feltételezni, hogy a kulturális jellemzốk „kulturális kiválasztódása” mindig „okkal” történik - mindig valamilyen, a gazdaszervezet számára vélt (vagy akár hamisan elvárt) haszon céljából. Mindig feltehetjük azt a kérdést, hogy vajon a gazdaszervezetek, a humán közvetítôk, akik vírushordozóként játszanak szerepet, látnak-e valamilyen hasznot (ami azt illeti jót vagy rosszat) abban, hogy segítsék a szóban forgó kulturális tárgyak megôrzését vagy továbbörökítését. Fel kell azonban készülnünk rá, hogy a válasz lehetséges, hogy „nem” lesz. Más szavakkal, valóságos lehetőségként kell kezelnünk azt a feltételezést, miszerint az emberi gazdaszervezetek, egyénileg, vagy csoportosan, lehetnek közömbösek, vagy tudatlanok bizonyos kulturális tárgyakkal kapcsolatban, vagy akár egyenesen elleñezhetik azokat, amelyek ennek ellenére képesek saját céljaikra kihasználni a gazdaszervezetet. A kulturális közvetítés és fejlődés legismertebb esetei azok az újítások, amelyek valamilyen közvetlen vagy közvetett haszonnal járnak a befogadó szervezet darwini, azaz genetikai alkalmasságára nézve. Egy jobb horog több halat fog, több szájat etet, több unokát segít a túlélésben, és így tovább. Az egyetlen különbség az erősebb kar és a jobb minôségú horog között az alkalmasságra gyakorolt hatás (képzelt) felbecsülésében az, hogy az erôs kart viszonylag direkt módon lehet - esetleg - átörökíteni genetikai úton, míg a horgot egyértelmúen csak kulturálisan lehet továbbörökíteni. (Ugyanakkor természetesen az erôs kart is lehet kulturálisan továbbörökíteni.) A body-building hagyománya például magyarázattal szolgálhat arra nézve, hogy egy közösségben miért találunk nagy százalékban erôs karral rendelkezô felnôtteket annak ellenére, hogy a (genetikailag) örökölt, erôs, felnőtt kar csak kis százalékban jellemző. De függetlenül attól, hogy milyen módon kerül továbbadásra az erôs kar, vagy a horog, a genetikai rátermettség szempontjából mindenképpen jó vételnek kell tekintenünk óket. Ez az alku azonban lehet rövid életû, vagyis csak rövidtávon kedvezô. Elvégre hosszútávon még a mezőgazdaság is kétséges üzletnek tűnhet, hogyha a darwini rátermettséget tekintjük a legfóbb jónak. (A vadászó-gyújtögetô életmód bizonytalan hasznokért való elhagyásáról szóló izgalmas leírást lásd Diamond, 1997.) De akkor milyen alternatívák maradnak?

Elôször is meg kell jegyeznünk, hogy rövidtávon, (evolúciós szempontból nézve, vagyis néhány évszázad, vagy akár évezred tekintetében) egy dolog virulhat függetlenül attól, hogy hajtott-e valóságos hasznot a genetikai rátermettség szempontjából. Ez a virágzás azonban szoros összefüggésben van azzal, hogy látszólag hasznos-e a genetikai rátermettség szempontjából. Még ha egyet is értünk azzal, hogy a darwini alkalmasság növelése a kulturális evolúció alapvetô hajtómúve, akkor is rögzítenünk kell a megtartás és átadás néhány gyorsabb, azonnalibb mechanizmusát. Ezeket nem nehéz 
megtalálni. A kulturális szereplốk valószínúleg kihasználják azokat a gépezeteket, amelyek a múltban az alkalmasságot fokozó jellemzóket és preferenciákat testesítettek meg. Mindannyiunk számára genetikusan biztosított egy minőségi tér, amelyben bizonyos dolgokat jónak érzünk, míg másokat nem. A szabály pedig, ami szerint élünk a következô: ha jó érzés, akkor tartsd meg. Ez az elnagyolt és kész szabály természetesen kijátszható. Az édesszáj kihasználásához közvetlenül kapcsolódó kulturális javak használati tárgyak, szokások, receptek, mezőgazdasági minták, kereskedelmi utak robbanásszerú elterjedésének minden bizonnyal jelentôs negatív összhatása volt az ember genetikai rátermettségére. Rá kell mutatnunk, hogy ezeknek a kulturális tárgyaknak a megjelenésére az a magyarázat, miszerint „látszólag” haszonnal járnak a genetikai rátermettség számára, nem kötelez el bennünket arra, hogy elfogadjuk azt az (abszurd) állítást, hogy az emberek (tévesen) úgy gondolják, hogy a cukor beszerzésével és fogyasztásával növelhetik genetikai rátermettségüket. Az ésszerúség nem az övék, hanem az anyatermészeté. Ốk csak azt követik, amit szeretnek.

Mégis, annak tudatában, hogy mit szeretnek, racionális döntéseket hoznak, és meglehetősen találékony módon és gyakran lenyügöző előrelátással választják meg, hogy hogyan szerezzék meg, amit szeretnek. Ez még mindig a kulturális evolúció hagyományos modellje, amelyben az ágensek a saját igényeik kielégítésének maximalizálásától vezérelve gazdálkodnak javaikkal - és preferenciáikat, meglehetősen közvetlenül, genetikai örökségükből kapják. Ennél is érdekesebb lehetőség olyan új preferenciákhoz jutni, amelyek maguk is valamiféle kulturálisan átörökített szimbiózis következményei. Mindegyiküknek a maga erejéból kell felkapaszkodnia a memoszférába, úgy, hogy kiaknáz valamilyen előre meghatározott preferenciát, de ez a rekurzív folyamat, - amely a genetikai evolúció gleccser-tempójához viszonyítva nyaktörố sebességgel száguldhat -, korlátlan messziségekre viheti a humán ágenseket az eredetei genetikai kiindulópontjuktól. Egy gyakran idézett bekezdésben E. O. Wilson ezt másképp állítja:

A gének pórázon tartják a kultúrát. Bár a póráz nagyon hosszú, elkerülhetetlen, hogy az értékek az emberi génparkra gyakorolt hatásuk alapján körvonalazódjanak. (Wilson, 1978:167)

Véleményem szerint ez a póráz végtelenül hosszú, abban az értelemben, hogy azok a megszorítások, amelyekrôl Wilson beszél, olyan esetlegesen alkalmazottak, esetleges sajátságaik szerint kiaknázottak és tehetetlenül múködők lehetnek a kulturális termékek és meta-termékek rekurzív zuhatagában, hogy egyáltalán nem világos, hogy léteznek-e olyan pontok a képzeletbeli kulturális térben, amelyeket elvileg még nem foglalt el valamiféle termék, amely végső soron - Wilson történelmi eseményekből álló pórázának segítségével - ne lenne visszavezethető a génekre. Ezen képzeletbeli pontok közül számos, minden kétséget kizáróan genetikai zsákutcának bizonyulna (a pontok elfoglalásának következményeként a homo sapiens-t előbb vagy utóbb a kihalás fenyegetné), bár ez nem lehet kifejlődésük akadálya a sebes tempójú kultúratörténet idején. Nemcsak ízléseket, hanem meta-ízléseket is szerezhetünk. Vagyis a kultúrában felfedezhetünk, s ennek következtében alkalmazhatunk egy olyan ízlést, amelyből aztán kifejleszthetünk további kívánatos ízléseket, és így tovább. Mindegyik fázisban számíthatunk arra, hogy találunk parazitákat, kommenzalistákat és mutualistákat - kategorizálni azonban csak akkor tudjuk óket, ha az új környezetben is feltesszük a Cui bono? azaz a Ki jár jól? kérdést, és ilyen vagy olyan eseti meghatá- 
rozást hozunk. Ami az egyik embernél iskolázott, múértố viselkedés, az a másiknál a bóvli konzumfogyasztása. Az „utazás”, a „gyújtő lét”, a „hobbival rendelkezés” vagy a „önmagam képzése” meta-mémeket magukat is tekinthetjük úgy, mint az elôre megalapozott személyes (de többé már nem genetikai értelemben vett) preferenciák kiaknázóit vagy ösztönzőit. Érdekes, hogy a hétköznapi nyelvben ezeket a preferenciákat gyakran „gyengeségeknek” nevezzük, mint például a következô mondatban: „Az érett sajt (vagy a szójátékok, vagy a vörös-hajúak) a gyengém”, ügyesen felállítva egy normát, amelytől azonban ugyanazzal a lélegzettel el is határolódunk.

Ez az a fő́ pont Dawkins meglátásából, amit hangsúlyozni szeretnék. Azok a mémek fognak elburjánzani, amelyek - ha törik, ha szakad - mindenáron szaporodnak. Képzeljék el óket, amint behatolnak a kultúra tagjainak agyába és ott fenotípus változásokat okoznak, majd pedig alávetik magukat a nagy kiválasztódási versenynek Csakhogy nem a darwini genetikai rátermettség versenyének(az élet ahhoz túl rövid), hanem a dawkinsi mém rátermettségi versenynek. Itt az „ô”, mint mémek rátermettsége van mérlegen, nem pedig a befogadó szervezet genetikai rátermettségeként. A környezet pedig, mely megtestesíti azt a kiválasztási kényszert, ami meghatározza a rátermettséget, nagymértékben más mémekből tevődik össze.

Miért tûri ezt a gazdaszervezet? Miért kellene a homo sapiens tagjainak állni a megkülönböztetô reprodukció egy teljesen új rendszerének megalapítási költségeit? Felhívom az olvasó figyelmét arra, hogy a kérdés, amit itt felteszünk és megválaszolunk párhuzamos azzal a kérdéssel, amit az élősködő szimbionta és a gazdaszervezet kapcsolatáról kérdeztünk: miért viseli el a gazdaszervezet? A válasz röviden az, hogy a kiirtás, megsemmisítés túlságosan költséges lenne. Ez azonban csak annyit jelent, hogy az előnyök, amiket a paraziták által kihasznált gépezet élvez, olyan mértékủek, hogy a gépezet megtartása és a paraziták eltűrése (már amennyire tolerálják óket) az eddig felmerült lehetố legjobb megoldás. Függetlenül attól, hogy hosszútávon (millió évek elteltével) erre a fertőzésre úgy tekintünk-e majd, mint mutualizmusra, kommenzalizmusra, vagy élősködésre, rövidtávon (az utóbbi néhány évezred során) az eredmény igen látványos volt: egy új típusú biológiai entitás, a személy megalkotása.

Szeretem összehasonlítani ezt a fejlôdést az eukarióták több mint egymilliárd évvel korábbi megérkezésével. A viszonylag egyszerú prokariótákat szomszédaik megtámadták és leigázták és a következésképpen létrejövő endoszimbiotikus csoportok jóval életképesebbek lettek és virágzásnak indultak, lehetôvé téve egy biológiai forradalom kitörését. Az eukarióták, prokarióta unokatestvéreikkel egymás mellett élve, de náluk sokkal bonyolultabbakként, sokoldalúbbakként és alkalmasabbakként megnyitották a tervezésre alkalmas teret a többsejtú szervezetek létrejöttéhez. Ehhez hasonlóan a kultúrával fertốzött hominidok kiemelkedése megnyitott egy újabb területet, az eleddig lakatlan és áttekinthetetlen tervezési térből. Mi az állati „unokatestvéreinkkel" élünk egymás mellett, de mi sokkal összetettebbek, sokoldalúbbak és alkalmasabbak vagyunk. Amennyiben erôinket egyesítjük mémjeinkkel, akkor új jelölteket teremtünk az elő́nyök hasznosítására, illetve új válaszokat a Cui bono? kérdésre.

\section{Két, túlságosan is szokványos ellenvetés}

Az ember gyakran hallja azt a véleményt, hogy azok a módok, ahogy a kulturális entitások fejlődnek igen erôs ellentétben állnak a darwini elmélettel. Különösen két 
állítás győzedelmeskedik gyakorta, az egyik szerint: a kulturális evolúció a darwini evolúcióval ellentétben lamarcki; a másik pedig azt állítja, hogy a kulturális evolúció a darwini evolúciótól eltérően tele van „vízszintes átadásokkal”, azaz a szerkezet elemei az öröklődési szabályok követelményei nélkül, szabadon ugrálhatnak egyik leszármazási ágból a másikba. Valamikor az emlôsök és a hüllốk két teljesen különbözô fejlődési útra léptek, és így a hüllőknél bekövetkezett újítások nem kerülhetnek át az emlősök csoportjába, hanem csak a leszármazott hüllőknél érvényesülhetnek. Ez a megszorítás azonban a kulturális evolúcióban nem létezik. Jómagam többször is érdeklődtem, hogy miért nem hallunk többször egy harmadik különbségrôl is, miszerint a kulturális ötletek nem szexuális úton reprodukálódnak. Pontosabban szólva nem szükséges, hogy a mama és papa ötletek összekerüljenek annak érdekében, hogy mindkét nemhez tartozó, kisgyerek ötleteket hozzanak létre. Valószínúleg azért nem hallani erről a gondolatról, mert a homlokára lenne írva, hogy számító vagyok - egy lusta (vagy kétségbeesett) kísérlet arra, hogy kifogást találjunk arra, hogy miért nem gondolkodunk tovább a kultúra darwini értelemben vett jellemzôiről. Végül is a szexuális reprodukció nem kötelező eleme a darwini egyedfejlődésnek, mivel biztosan állíthatjuk, hogy az összes darwini evolúció, amely valaha végbement a Földön, 99\%-a aszexuális módon reprodukálta az átörökítôket. Továbbá, annak ellenére, hogy milyen hatalmas mértékben zajlik napjainkban a szexualitás, maga is csak egy kialakult, kifejlődött vonás, nem pedig a darwini evolúció előfeltétele. Ebből következően a szexuális reprodukció hiánya a memoszférában, nem jelent kihívást az új darwinista magyarázatok számára. Egyúttal azonban pontosan ugyanezt a megfigyelést tehetjük a lamarckizmus tartalmi különbségeirôl és a vízszintes átadásról, vagy az anasztomózisról (a családfa egyesítésrôl).

Vegyük a lamarckianizmust elốször. Az új darwinista nézetek, Weissmantól kezdődôen, úgy látják, hogy az alkalmazás közben elsajátított jellemzőket nem lehetséges a leszármazottaknak genetikai úton átadni. Közismerten maga Darwin is kész volt elfogadni a lamarckizmus ezen jellemzôjét, de hosszú ideig félreértelmezték. Weissman különbségtétele az öröklődési lánc - nagyvonalakban a pete és a sperma -, illetve a szomatikus sejtek - vagyis az összes többi sejt - vonatkozásában újra és újra igaznak bizonyult. Ma már tankönyvszagú igazságnak számít az is, miszerint nincsen mód arra, hogy a szomatikus újítások átkerüljenek az öröklési láncba. Annak ellenére, hogy az irodalom gyakran komolyan tárgyalja különböző egzotikus lehetőségek kérdését, amelyek minden bizonnyal léteznek valamely tiltott zugban. Meg kell azonban jegyeznünk, hogy ez az ortodox módszer a lamarcki jelenségek azonosítására (mint olyan dolgok, amelyek nem történnek meg) kifejezetten csak a többsejtű szervezetek esetében érvényes. Mi számít lamarcki jelenségnek a baktériumok és a legôsibb életformák vagy a vírusok világában? A vírus esetében, amit én úgy jellemeztem, mint egy attitûddel rendelkezô DNS láncolat, nincsen határvonal a szomatikus és az öröklési vonal között. Ha valami megváltoztatja ez egyedi vírusláncolatot, azt genotípus változásnak - mutációnak - nevezhetjük, ha ez a változás továbbadódik a reprodukció során. Egyébként csak fenotípus változásnak tekintjük. Nem arról van szó, hogy nem lehet egy ilyen vonalat meghúzni, hanem arról, hogy ha meg is húzzuk a vonalat, tulajdonképpen semmit nem akadályoz meg. Az az állítás tehát, amit a lamarckizmus a vírusok világában magának tulajdonított, ily módon Pickwick-ivé válik. Mivel pedig a mémek legalább annyira nem többsejtúek, mint amennyire nem szexuálisak, a tény, 
hogy nincs világos - vagy ahogy azt a MIT intézetben szoktuk mondani „elvi alapon álló” - módja annak, hogy a mutációkat a fenotipikus szerzett tulajdonságoktól megkülönböztessük, aligha mutatja azt, hogy eleve ki lennének zárva az új-darwinista megközelítésbôl. A Földünkön kifejlődött élet legnagyobb része, több mint $99 \%$-a, ilyen rendszerben alakult ki, aminek evolúciójával az új darwinizmus készséggel foglalkozik. Egyúttal ugyanez az ítélet vonatkozik az anasztomózisra is, bár ez egy újabb keletû és kevés lelkesedéssel fogadott felfedezés: számos vízszintes átadásra találunk példát az egysejtûek és a baktériumok evolúciójában - egy tény, amely segítségével megpróbálkozhatunk azzal, hogy önálló baktériumcsaládokat határozzunk meg, „elvi alapon álló" módszerekkel - és itt még egyszer megismétlem, hogy ezen a bolygón az evolúció legnagyobb része ilyen apró mozzanatokban zajlott. Abban a pillanatban, ahogy figyelmünket a saját többsejtủ és szexuális úton reprodukálódó fajunkról a bolygónkon sokkal nagyobb számban fellelhető más fajok felé fordítjuk, ezek a szokványos ellenvetések azonnal sokat veszítenek erejükból, ha nem is gyengülnek el teljesen. A mémek valóban igen kevéssé hasonlíthatók össze az elefántok gemomjával, na de akkor mi van?

\section{De mi a helyzet az emberi értelemmel - és kreativitással?}

A zavar, ami a gondolkodók képzeletét más irányba tereli - gyanúm szerint Darwinnak a nemesítés, a mesterséges (szándékos/tudatos) állati nemzés és a „tudattalan" (a háziállatok körében tapasztalható kedvenc utódok akaratlan elônyben részesítése) kiválasztódásról alkotott eredeti gondolatának enyhe félremagyarázatából ered, amely ezt a gondolatot összefüggésbe hozza a - szintén Darwin által megfogalmazott - természetes kiválasztódással. Darwin törekedett arra, hogy ellentétbe állítsa a természetes kiválasztódás során meglévő előrelátás és szándék teljes hiányát a szándékos, célzott viselkedéssel a mesterséges kiválasztódásban, hogy bemutassa, a természetes folyamat elviekben mindenféle gondolkodás nélkül is múködhet. Ennek ellenére azonban nem fektette le azt a tételt (ellentétben azzal, ahogy ezt sokan gondolják), miszerint a szándékos, célok vezérelte, tudatos kiválasztódás a természetes kiválasztódás egyik vállfaja lenne! A tacskók rövid lábai, vagy a Holstein marhák hatalmas tôgyei éppen annyira a természetes kiválasztódás eredményei, mint a sasok szárnyai. Mindezek természetesen fejlődtek ki egy olyan környezetben, ahol a különlegesen jól összpontosított, emberek közvetítettel szelektív nyomás is jelen volt. Ezekre a testi, fenotipikus változásokra az öröklési genetika ugyanazon törvénye és ugyanaz a reprodukciós dinamika érvényes, mint az egyéb olyan változásokra, amelyek ezen speciális és extrém esetében az alap esetben érvényes szelektív nyomás „véletlenszerűsége” és kuszasága jelentôsen lecsökkent mértékben van jelen.

A fenti tételbôl, a kulturális evolúciót nézve, a következô következtetést vonhatjuk le: nincs konfliktus a között a két állítás között, hogy a tárgyi leletek (beleértve az olyan absztrakt, leleteket is, mint a mémek) a természetes kiválasztódás termékei, és hogy ezek egyben (gyakran) a tudatos emberi tevékenység előrelátható és tervezett eredményei. A jelek arra utalnak, hogy az újonnan kialakuló evolúciós archeológiai iskola néhány gondolkodója elkövette ezt a hibát. Boone és Smith kritikája szerint több evolúciós archeológus úgy gondolja, hogy az egyetlen útja annak, hogy gyakorlatiasak és tudományosak legyenek a darwini kulturális evolúcióval kapcsolatban az, 
hogy elvetik a szándék és a racionalitás meglétét az emberi kultúra-csinálók esetében. Inkább a „kiválasztódást választják a döntéshozás helyett” (Boone \& Smith, 1998:11). Ez egyszerúen hiba, ugyanabból az okból kifolyólag, amiért hiba lenne azt hinni, hogy a versenygalambok díszes tollazata döntéshozás, és nem a kiválasztódás eredménye. Sajnos, Boone és Smith beleesnek ugyanabba a csapdába, amikor a kanadai Cree népcsoportokban, a hómobilok elterjedésének érdekes jelenségét tárgyalják. Tökéletesen igazuk van, amikor azt állítják, hogy a hómobilok alkalmazása a cree-k által nem tekinthető úgy, mint a hómobil használók megkülönböztetô biológiai fejlődésének eredménye, ugyanakkor félreértelmezik az ennél sokkal izgalmasabb mémszempontú nézôpontot, mivel azt mondják, hogy:

„A változat, miszerint a "hómobil ${ }^{8}$ mémek» sokkal hatékonyabban öröklődtek át a Cree nem-leszármazottakra (csakúgy, mint az utódokra), mint a "hócipő mémek» hangsúlyozottan nem természetes kiválasztódás. Pontosabban épp ugyanazt az alkalmazkodó döntéshozatali mechanizmust igényli, amelyet az evolúciós archeológusok szeretnének kiiktatni az archeológiai magyarázatokból.” (Boone és Smith, 1998:12).

Ezzel ellentétben, ha abból a mém-szempontú nézôpontból vizsgáljuk meg a dolgot, amely a rátermettségével a hómobil mémet tekinti az örökítônek, akkor a kulturális evolúciót tekinthetjük az „alkalmazkodó döntéshozatal” és a természetes kiválasztódás együttes eredményének is. Vegyük például, a háziasított lovak rátermettségét, amelyek az első példányok megjelenése után igen gyorsan terjedtek az amerikai indiánok körében, majd az autó megjelenésével számuk rohamosan fogyni kezdett. Ezek a genetikai fluktuációk természetesen azon szelektív erők változásának a hatásai, amelyek a lovak különbözó életkörnyezeteiben múködtek. Valamint annak a ténynek következményei, hogy a tudatos, elốrelátó emberi közvetítốk kulcsszerepe a fent említett szelektív környezetben, semmiképp nem emeli ki a jelenséget a természetes kiválasztódással lejátszódǒ szokványos genetikai evolúció tartományából.

Steven Pinker is azok közé tartozik, akik szemet hunynak e fölött a tény fölött. Pinker a Hogy múködik az agy? (1997) címú könyvében egy rövid szakasszal elintézi a kulturális evolúciós modellek kérdését:

„Ne legyünk már olyan prózai gondolkodásúak! - mondják a kulturális evolúció hívei. Természetesen a kulturális evolúció nem a darwini változat pontos mása. A kulturális evolúcióban a mutációk irányítottak és a megtanult jellemzők örökölhetők. Lamarck ugyan tévedett a biológiai evolúcióval kapcsolatban, de a kulturális evolúcióról alkotott nézetei igaznak bizonyultak. Azt állítani, hogy a kulturális evolúció lamarcki, felér egy beismeréssel arról, hogy az illetőnek fogalma sincs arról, hogy hogyan is múködik a kulturális evolúció. A kulturális termékek feltűnő jellemzői, úgymint találékonyságuk, szépségük és igazságuk (hasonlóan a szervezet komplex alkalmazkodó felépítéséhez) azokból a gondolati számításokból erednek, amelyek «irányítják - azaz kitalálják - a mutációt» és amelyek «megszerzik - vagyis megértik - a jellemzóket»" (Pinker, 1997:209).

Pinker nem a megfelelố párhuzamot vonta meg. Nem Lamarck modellje, hanem Darwin mesterséges kiválasztódásról szóló modellje (amely a természetes kiválasztódás egy speciális esete) az, amelynek segítségével értelmezhető az a jelenség, amelyre a fenti szakaszban felhívja a figyelmünket. Ironikus, hogy Pinker átsiklik e fölött, hiszen a kulturális jelenségek, amelyeket ô maga állított az evolúciós szempontból tervezett rendszerek példájaként, vagy a nyelvi jelenségek semmiképpen sem egy 
előrelátó, találékony és szándékos emberi felfedezés eredményei. Az emberi nyelvek egyes vázlatos jellemzôi minden kétséget kizáróan genetikailag örökíthetôk, de több más vonás, mint például a kiejtésben való változások, teljesen bizonyosan kulturálisan öröklődnek, tehát a kulturális evolúció termékei, nem pedig a genetikaié.

Egyes mémek úgy viselkednek, mint a háziasított állatok. Az általuk hajtott haszon miatt értékeljük óket, a szaporodásukat pedig az ember viszonylag jól megérti és nagymértékben elő is segíti. Más mémek a patkányokhoz hasonlíthatóak, amelyek jól élnek és növekednek az ember környezetében, annak ellenére, hogy a vonakodó gazdáik, bár eredménytelenül, negatívan diszkriminálják ốket. Megint más mémek olyanok, mint a baktériumok, vagy más vírusok, amelyek azon „igyekezetükben”, hogy egyik gazdaszervezettôl a másikig jussanak, irányítják az emberi viselkedés bizonyos aspektusait (például a tüsszentés kiprovokálása). A „jó” mémeknek - mint például a számolás és írás mémjeinek - van mesterséges kiválasztása. Ezeket a mémeket aztán gondosan megtanítják minden új generációnak. Létezik azután a mémek nem tudatos kiválasztódásának mindenféle változata is. Egy példa lehet az árnyalatnyi kiejtésbeli változások, amelyek feltételezhetôen valamilyen hatékonyságnövelés miatt terjedtek el a nyelvi csoportokban, de az is elképzelhető, hogy csak potyautasként csapódtak valamelyik emberi preferencia kifejezéseihez. Vannak olyan tudattalan mémkiválasztódások is, amelyek egyértelmúen veszélyesek. Ezek az emberi döntéshozatali rendszer folyamataiban ejtik zsákmányaikat, ahogy azt a genom lehetôvé teszi, amelyet aztán egyéb kulturális újítások erősítenek és igazítanak. Jó példa erre az „elraboltak az ufók”-mém, amely tökéletes értelmet kap akkor, amikor a saját életképességét tekintjük a kulturális örökítôjének. Csak a mémszempontú nézőpont teszi tehát lehetôvé, hogy mindezeket a lehetőségeket egyetlen nézetben egyesítsük.

Végezetül, a mémekkel kapcsolatos ellenérzés egyik apadatlan forrása az a fenyegetố gyanakvás, hogy az emberi elme megismerése során, a mém-parazitáktól hemzsegő agyak képe aláaknázza az emberi kreativitás nemes hagyományait. Ezzel ellentétben én úgy gondolom, hogy világos, hogy csakis a kreativitásnak a mémek szempontjából történô számbavétele ad jó esélyt arra, hogy valamiképp a※onosulhassunk a saját agyunk termékeivel. Mi emberek napi szinten bocsátunk ki melléktermékeket, de a gyerekkorunk elmúltával már soha többé nem szemléljük ürülékünket a szerző vagy a mûvész büszkeségével. Ezek csak biológiai melléktermékek, és jóllehet, rendelkeznek saját, szerény egyéniséggel és jellemzốkkel, ez egyáltalán nem az, amit éltetünk bennük. Hogyan tudjuk igazolni, hogy büszkeséggel tekintünk szegény fertôzött agyunk mém-célpont mivoltára? Úgy, hogy azonosulunk a bennünk lakozó mémek egy alcsoportjával. Miért? Mert a bennünk található mémek között vannak olyanok is, amelyek nagyra értékelik az azonosulást épp egy ilyen mém-alcsoporttal! E mémszülte attitűd hiánya esetén, mi pusztán az interakció helye lennénk. Nekünk azonban vannak ilyen mémjeink, melyek meghatározzák, hogy kik vagyunk.

\section{4. Összefoglalás}

A lehetôségek ezen skáláját - kezdve a kultúra által szült vírusok (az összes ,attitûd”) akaratlan, nem tudatos hordozásától, az újítások és alkotások (amelyek intelligensen és múvészien használják fel a jól-megértett kulturális forrásokat) elôrelátó tervezéséig és kihirdetéséig -, egyetlen közös nézőpontból kell vizsgálni. Csak ebből 
a szemszögből érthetjük meg azt a pályát, amit mi, és csakis mi jártunk be, és amely átvitt minket a saját önző génjeink korlátain azáltal, hogy a kiválasztás új környezetét teremtette meg: a személyeket és azok termékeit, ami cserébe teljességgel új, egyedülálló válaszokat adott a Cui bono? (Ki jár jól?) kérdésre. A kulturális evolúció ilyen szemlélete nem tagadja az értékelés úgynevezett agy-šempontú nézópontja felé való továbblépés lehetőségét. Sốt pontosan ez az, ami lehetôvé teszi - minden külső segítség nélkül - az ez irányú elmozdulást.

Gruber Andrea fordítása

\section{JEGYZETEK}

${ }^{1}$ Ennek a bekezdésnek egyes részei Dennett elókészületben lévő művéből származnak.

2 Természetesen az ilyen szervezetet nem szükséges tudatos döntéshozónak tekinteni, de a „döntések” ésszerúségét, amelyeket meghoznak, általában az egyéni szervezet számára várható előnyökre alapozzák. Az ilyen döntésekben a gének, egyének, és a csoport szintjén jelentkezô előnyökrốl lásd Sober és Wilson (1998) művét.

3 Sober és Wilson (1998) rámutatnak, hogy a kulturális evolúcióról szóló modelljükben van egy áthidalhatatlan rés: „Elmondhatjuk, hogy (az ember egyéni és csoportos alkalmasságára nézve) haszonnélküli viselkedések sokkal gyakoribbnak tûnnek az ember esetében, mint más fajoknál, de nem tudjuk megmagyarázni, hogy miért alakult ki a haszonnélküli viselkedés bizonyos kultúrákban. Az ilyesfajta megértéshez valószínúleg a szóban forgó kultúra történelmének alapos ismerete szükségeltetik, és kiderülhet, hogy néhány ilyen viselkedés jórészt véletlenek folytán alakult ki" (Sober, Wilson, 1998:171).

4 Az igazat megvallva, a horgasféreg génjeinek (vagy a horgasféreg „csoport” génjeinek) reproduktív távlatairól szólva, Sober és Wilson (1998:18) a D. dendriticum önzetlen viselkedésérôl szóló példájában rámutat arra, hogy a horgasféreg, amely a hangya agyában az irányítást végzi tulajdonképpen kamikaze módjára viselkedik, mivel úgy hal meg, hogy esélye sincs arra, hogy a génjeit továbbadja, hasznára léve ezzel a hangya más részeiben élô, (nem szexuális úton reprodukált) kvázi-klónjainak.

5 Boyd és Richerson (1992) kimutatja, „hogy gyakorlatilag bármilyen viselkedés stabilizálódhat egy társadalmi csoporton belül, ha a társadalmi normák kellő mértékben támogatják azt.” (Soberés Wilson, 1998:152)

6 Valójában a kulturális evolúció lamarcki természetéról szóló rövid és nem túlságosan beható leírásokban, amelyekkel én találkoztam, sohasem mondják ki világosan, hogy melyek azok az entitások, amelyek képesek a tanult jellemzók továbbadására. Azt gyanítom, hogy a tiltakozóknak az a szigorúan nem-idevágó tény volt homályosan az agyában, miszerint az emberi gazdaszervezet képes továbbadni a többi humán gazdaszervezetnek olyan kulturális tárgyakat, amelyeket ő is élete során sajátított el. Ez azonban egyáltalán nem lamarckizmus.

7 Ez a rész Dennett mûvéból származik, 1998.

${ }^{8}$ Hómobil: egy kisméretű jármú, mely elől kormányozható sítalpakon, hátul pedig meghajtott lánctalpakon áll. Ülốkéjén terpesz-tartásban közlekedhetünk a havon.

9 A mém-szempontú nézőpont sok egyéb elméleti szempontot felvet, de azok már egy másik vizsgálat tárgyát képezik.

\section{IRODALOM}

Boone, James L. \& Smith, Eric Alden, (1998): Az evolúciós archeológia kritikája (A Critique of Evolutionary Archeology), In: Jelenkori antropológia (Current Anthropology). Különki- 
adás, kiegészítés, 1998. június.

Bo Dahlbom, szerk. (1993): „Az agy vírusai” (Viruses of the Mind), In: Dennett és- kritikusai (Dennett and his Critics), Oxford: Blackwell.

Boyd, Robert \& Richerson, Peter J., (1985): A kultúra és az evolúciós folyamat (Culture and the Evolutionary Process), Chicago University Press.

Boyd, Robert, \& Richerson, Peter J., (1992): A büntetés lehetôvé teszi az együttmû́ködés (vagy bármi más) kialakulását nagyméretű csoportokban (Punishment Allows the Evolution of Cooperation (or Anything Else) in Sizable Groups), In: Etológia és Szociobiológia (Ethology and Sociobiology), 13:171-95

Cavalli-Sforza, Luca, \& Feldman, Marcus, (1981): Kulturális közvetítés és evolúció: egy mennyiségi megközelítés (Cultural Transmission and Evolution: A Quantitative Approach), Princeton, NJ: Princeton University Press.

Dawkins, Richard, (1976): Az önzố gén (The Selfish Gene), 2. kiadás, 1989, Oxford: Oxford University Press.

Dennett, Daniel C. (1998): „Hómobilok, lovak, patkányok és mémek” (Snowmobiles, horses, rats, and memes), (Válasz „Az evolúciós archeológia kritikájá”-ra (James L. Boone és Eric Alden Smith A Critique of Evolutionary Archeology), Jelenkori antropológia (Current Anthropology). Különkiadás, kiegészítés, 1998. június.)

Diamond, Jared, (1997): Puskák, baktériumok és acél (Guns, Germs and Steel)

Lumsden, C. \& Wilson, E. O. (1981): Gének, az agy és a kultúra (Genes, Mind and Culture), Cambridge, MA: Harvard University Press.

Pinker, Steven, (1997): Hogy múködik az elme? (How the Mind Works), New York: Norton.

Ridley, Mark, (1995): Állati viselkedés (Animal Behaviour) 2. kiadás, Boston: Blackwell Science.

Sober, Elliott \& Wilson, David Sloan, (1998): Másokért: Az önzetlen viselkedés evolúciója (Unto Others: The Evolution of Unselfish Behavior), Harvard University Press.

Wilson, E. O., (1978): Az emberi természetről (On Human Nature), Cambridge, MA: Harvard University Press.

Előkészületben: „Az értékelők evolúciója” (The Evolution of Evaluators) a Siena mühely kötetében az evolúciós közgazdaságról. 